\title{
USING OF SOME BIFIDOBACTERIA SPECIES AS BIOPRESERVATIVE CULTURES IN SOME DAIRY PRODUCTS
}

\author{
HEND A. ELBARBARY \\ Department of Food Control, Faculty of Veterinary Medicine, Benha University \\ Tel.: +20 40212 3529; Fax: +20 132463074 \\ E-mail address: hendbarbary2002@ yahoo.com (H.A. Elbarbary). \\ Full postal address: Department of Food Control, Faculty of Veterinary Medicine, Benha University, Moshtohor 13736, \\ Kaliobyia, Egypt.
}

\section{ABSTRACT}

Received at: 9/9/2014

Accepted: 19/10/2014
The effect of using bifidobacteria spp. in the manufacturing of yoghurt and low salt soft cheese on the growth of Escherichia coli and Staphylococcus aureus was studied. When B. bifidum or B. longum was inoculated with these bacteria, the numbers of their population gradually decreased and disappeared in yoghurt on the $15^{\text {th }}$ and $10^{\text {th }}$ day of storage period at $4^{\circ} \mathrm{C}$ for E. coli, respectively. On the other hand, Staph aureus population was disappeared on the $10^{\text {th }}$ and $7^{\text {th }}$ day of storage period. Addition of $B$. bifidum or B. longum inhibited the growth of E. coli and Staph aureus in low salt soft cheese during storage at $4^{\circ} \mathrm{C}$ after 7 and 5 days of storage in cheese inoculated with $B$. longum, respectively. While both organisms couldn't be detected on the $7^{\text {th }}$ day of storage in cheese inoculated with B. bifidum. The results of the current study indicated application of bifidobacteria spp. as biopreservative cultures in dairy products.

Key words: Bifidobacteria, E. coli, Staph aureus, Biopreservative, Fermented milks

\section{INTRODUCTION}

The use of probiotic culture to produce dairy products that claim health benefit as a part of the so called "functional foods" is a new trend in the dairy industry. The consumption of probiotic cultures positively affects the composition of gasterointestinal tract microflora and extends a range of host benefits which so far claimed to be; pathogens interference, immuno stimulation and immunomodulation, anticarcinogenic and antimutagenic activities, alleviation of symptoms of lactose intolerance, reduction in serum cholesterol, reduction in blood pressure, decrease incidence and duration of diarrhea, prevention of vaginitis and maintenance of mucosal integrity (Montes et al., 1995; Klaenhammer and Kullen, 1999; Parodi, 1999).

Fermented milks are considered as one of the oldest dairy products consumed widely all over the world. They characterized by high nutritive value as they considered an excellent source of high quality protein, calcium, phosphorus, potassium, magnesium and vitamin B (Robinson, 1991; Piaia et al., 2003). Fermented milks are generally fermented with a mixture of the two species, Streptococcus salivarius subspp thermophilus and Lactobacillus delbrueckii subspp bulgaricus. In recent years, fermented milks have become popular vehicles for incorporation of probiotic species (Guarner and Schaafsma, 1998).
Therefore, bio-yoghurt and/or probiotic cheese that contains live probiotic bacteria with concentration of above $7 \log _{10} \mathrm{cfu} / \mathrm{gm}$ at the time of consumption in order to claim beneficial health effects (Duggan et al., 2002). As bifidobacteria are the most important probiotic organisms that provide number of the above health benefits, they commonly used for preparation of new probiotic dairy products.

Bifidobacteria were grouped into 24 spp. but only 5 spp. of them (B. bifidum, B. longum, $B$. infantis, $B$. breve and $B$. adolescentis) have attracted attention in the dairy industry for the manufacture of functional fermented milk products (Tamime et al., 1995). B. bifidum and $B$. longum characterized by a high intestinal colonization and acid resistance which make them useful for incorporation in fermented milk products (Kheadr et al., 2002).

Many investigators detected food-borne spoilage and pathogens from the dairy products such as B. cereus, B. subtilis, B. licheniformis, B. pumilus, B. coagulans, B. polymyxa, B. megatericum, Staph aureus, $L$. monocytogenes, E. coli, Salmonella spp., Shigella spp. and Yersinia pastis (El-Zayat, 1988; El-Zayat et al., 1990). The use of probiotic culture is extremely important to safe production of white pickled cheese. The traditional method of cheese manufacturing is not considered safe practice, since food-borne pathogens can survive in the absence of these cultures (Abdalla et al., 1993). The antagonistic and biological 
preservation of probiotic culture attributed to the inhibition of other microorganisms through competition for nutrient and/or by production of one or more antibacterial active metabolites which play an essential role in ensuring the safety and extending the shelf-life of fermented foods (Devlieghere et al., 2004).

In sight of these facts, the aim of the current work is to study the incorporation of $B$. bifidum and $B$. longum in some fermented dairy products as biopreservative cultures against some pathogenic bacteria.

\section{MATERIALS and METHODS}

\section{Cultures preparation}

\subsection{Starter cultures}

Yoghurt starter cultures contain Streptococcus salivarius subspp thermophilus and Lactobacillus delbrueckii subspp bulgaricus (1:1) were obtained from Chr. Hansen's Laboratories, Horsholm, Denmark and Bifidobacterium bifidum ATCC 15696, Bifidobacterium longum ATCC 15707 were obtained from the Egyptian Microbial Culture Collection at Cairo Microbiological Resources (MIRCEN), Faculty of Agriculture, Ain Shams University, Egypt. Yoghurt starter cultures were transferred into sterile skimmed milk, then incubated at $40^{\circ} \mathrm{C}$ for $24 \mathrm{~h}$. Both bifidobacterial strains were reactivated by three consecutive subculturing on MRS broth supplemented with $0.05 \%$ (W/V) L-cystein- $\mathrm{HCl}$, then incubated anaerobically at $37^{\circ} \mathrm{C}$ for $18-24 \mathrm{~h}$ without agitation (Hull and Robert, 1984).

\subsection{Target bacteria}

Escherichia coli and Staphylococcus aureus were previously isolated from examined yoghurt samples in Department of Food Technology, Faculty of Agriculture, Benha University, Egypt. They were propagated till obtain approximately $6 \log _{10} \mathrm{cfu} / \mathrm{ml}$ from each strain.

\section{Antibacterial activity of Bifidobacterial species in some fermented milks \\ 2.1. Bifidus yoghurt}

Yoghurt was manufactured according to Robinson and Tamime (1994). Fresh cow's milk (3\% fat), obtained from dairy farm, Faculty of Veterinary Medicine, Benha University, was heated at $90{ }^{\circ} \mathrm{C}$ for 20 min, cooled to $40^{\circ} \mathrm{C}$ then portioned into two parts and inoculated with E. coli or Staph aureus at 6.65 and $6.75 \log _{10} \mathrm{cfu} / \mathrm{ml}$, respectively. Each part of inoculated milk was divided into 3 groups and was cultured with:

A) Yoghurt starter cultures, $S$. thermophilus and $L b$. bulgaricus (1:1) at a level of $2 \%$ for preparation of standard (control) yoghurt (T1).

B) The mixed probiotic culture contained B. bifidum, $S$. thermophilus and Lb. bulgaricus $(1: 1: 1)$ at a level of $2 \%$ for preparation of bifidus yoghurt (T2).

C) The mixed probiotic culture contained B. longum, $S$. thermophilus and Lb. bulgaricus (1:1:1) at a level of $2 \%$ for preparation of bifidus yoghurt (T3).

The inoculated milk was packaged into plastic cups and incubated at $40^{\circ} \mathrm{C}$ for $6 \mathrm{~h}$ and then stored at $4^{\circ} \mathrm{C}$. E. coli and Staph aureus counts of the resultant yoghurt were examined at zero time then after 1, 3, 7, 10 and 15 days of cold storage at $4^{\circ} \mathrm{C}$. Three trials were done for this experiment.

\subsection{Probiotic Cheese}

Low salt soft cheese was manufactured as described by Mehanna and Rashed (1990) and El-Sheikh et al. (2001) with slight modification. Reconstituted skim milk powder $(<1.25 \%$ fat,$<32 \%$ protein and $>53 \%$ lactose) was used for manufacture of cheese and $\mathrm{NaCl}(3 \%)$ were added to milk at $37^{\circ} \mathrm{C}$.

The bulk volume was divided into 6 groups, the first portion was inoculated by $E$. coli (T1), the second portion was inoculated by Staph aureus (T2), The third portion was inoculated with $B$. bifidum and $E$. coli (T3), the fourth portion was inoculated with $B$. bifidum and Staph aureus (T4), the fifth portion was inoculated with B. longum and E. coli (T5) and the sixth portion was inoculated with $B$. longum and Staph aureus (T6). Inoculated milks were kept at $37^{\circ} \mathrm{C}$ till proper curd was obtained, then the curd was kept to drain for $18 \mathrm{~h}$ in a previously sterilized stainless steel frames lined with cheese cloth. The obtained cheese with their respective whey were packaged in pre-sterilized aluminum cups and tightly covered with aluminum foil paper then kept at refrigerator for 15 days. Cheese samples were microbiologically examined for the counting of $E$. coli and Staph aureus at zero time and after 1, 2, 3, 5, 7 and 15 days. The experiment was repeated in triplicates and average results for each group were tabulated.

\section{Bacteriological analysis}

One gram of yoghurt was taken under aseptic conditions and used for bacteriological analysis. Also, cheese samples were homogenized with sodium citrate $(2 \%)$. Ten fold serial dilutions were prepared and cultured under optimum conditions for each examined bacteria. From each prepared dilution, 0.1 $\mathrm{ml}$ was transferred and evently spread over a dry surface of EMB and Baird Parker plates for enumeration of E. coli and Staph aureus, respectively, and the inoculated plates were incubated at $37{ }^{\circ} \mathrm{C}$ for 24-48 h (APHA, 1992).

\section{Statistical analysis}

Statistical comparisons were made by using one-way analysis of variance (ANOVA). The results were considered significantly different with $\mathrm{P}<0.05$ as described by Clarke and Kempson (1997). 


\section{RESULTS}

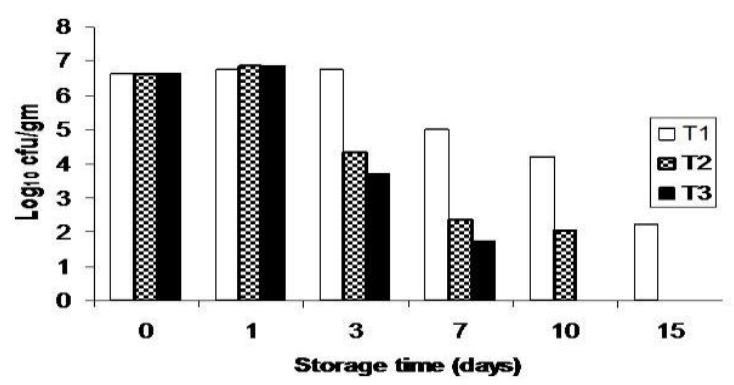

Figure 1

Viability of $E$. coli in bifidus yoghurt samples during refrigerated storage

T1: Yoghurt prepared with 2\% yoghurt starter culture

T2: Yoghurt prepared with $2 \%$ B. bifidum + standard yoghurt starter cultures

T3: Yoghurt prepared with 2\% B. longum + standard yoghurt starter cultures

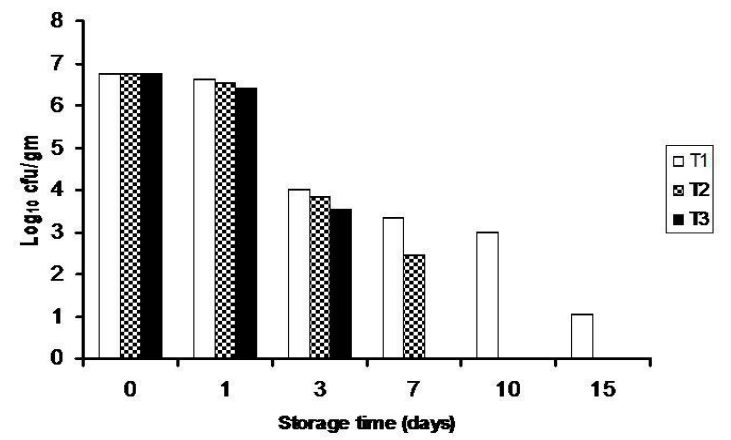

Figure 2

Viability of Staph aureus in bifidus yoghurt samples during refrigerated storage

T1: Yoghurt prepared with $2 \%$ standard yoghurt starter culture

T2: Yoghurt prepared with $2 \%$ B. bifidum+ standard yoghurt starter cultures

T3: Yoghurt prepared with $2 \%$ B. longum + standard yoghurt starter cultures

Table 1: Effect of bifidobactaria species on the growth of E. coli and Staph aureus in low salt soft cheese.

\begin{tabular}{|c|c|c|c|c|c|c|}
\hline $\begin{array}{c}\text { Storage } \\
\text { time (days) }\end{array}$ & $\mathrm{T} 1$ & $\mathrm{~T} 2$ & $\mathrm{~T} 3$ & $\mathrm{~T} 4$ & T5 & T6 \\
\hline 0 & $6.34 \pm 0.18^{\mathrm{al}}$ & $6.21 \pm 0.14$ abl & $6.34 \pm 0.11^{\mathrm{ab} 2}$ & $6.21 \pm 0.20^{\mathrm{bl}}$ & $6.34 \pm 0.10^{\mathrm{a} 2}$ & $6.21 \pm 0.13^{\mathrm{abl}}$ \\
\hline 1 & $6.38 \pm 0.11^{\mathrm{a} T}$ & $6.48 \pm 0.13^{\text {al }}$ & $6.37 \pm 0.21^{b 1}$ & $6.24 \pm 0.08^{\mathrm{c} 2}$ & $6.34 \pm 0.16^{\mathrm{c} 2}$ & $6.00 \pm 0.11^{\mathrm{acl}}$ \\
\hline 2 & $6.48 \pm 0.08^{a 3}$ & $6.66 \pm 0.09^{b 1}$ & $6.00 \pm 0.14^{\mathrm{bc} 3}$ & $5.65 \pm 0.17^{\text {bc2 }}$ & $5.00 \pm 0.16^{\mathrm{c} 3}$ & $5.12 \pm 0.15^{b c 2}$ \\
\hline 3 & $6.54 \pm 0.13^{a^{3}}$ & $6.75 \pm 0.10^{b 1}$ & $4.21 \pm 0.08^{\mathrm{b3}}$ & $4.35 \pm 0.22^{\mathrm{ab} 1}$ & $4.72 \pm 0.20^{\mathrm{aI}}$ & $3.30 \pm 0.09^{\mathrm{c} 2}$ \\
\hline 5 & $6.35 \pm 0.2^{\mathrm{a} 2}$ & $6.79 \pm 0.15^{\mathrm{a} 2}$ & $3.00 \pm 0.10^{\mathrm{c} 2}$ & $1.04 \pm 0.15^{\mathrm{a} 3}$ & $2.38 \pm 0.13^{b 1}$ & Nil \\
\hline 7 & $5.00 \pm 0.09^{\mathrm{a} 2}$ & $6.33 \pm 0.11^{\mathrm{b} 2}$ & ND & ND & $\mathrm{ND}$ & ND \\
\hline 15 & $4.43 \pm 0.14^{\mathrm{a} 1}$ & $6.33 \pm 0.11^{\mathrm{cl}}$ & ND & ND & ND & ND \\
\hline
\end{tabular}

T1: Soft cheese inoculated with E. coli (control)

T2: Soft cheese inoculated with Staph aureus (Control)

T3: Soft cheese inoculated with $E$. coli and $8 \log _{10} \mathrm{cfu} / \mathrm{ml}$ of B. bifidum

T4: Soft cheese inoculated with Staph aureus and $8 \log _{10} \mathrm{cfu} / \mathrm{ml}$ of B. bifidum

T5: Soft cheese inoculated with E. coli and $8 \log _{10} \mathrm{cfu} / \mathrm{ml}$ of $B$. longum

T6: Soft cheese inoculated with Staph aureus and $8 \log _{10} \mathrm{cfu} / \mathrm{ml}$ of B. longum

ND: Not detected

abc Values in the same row having different superscripts differ significantly $(\mathrm{P}<0.05)$.

123 Values in the same column having different superscripts differ significantly $(\mathrm{P}<0.05)$.

The values indicated were the mean of three trials \pm SD (Standard Deviation). 


\section{DISCUSSION}

\section{Viability of E. coli and Staph aureus in bifidus yoghurt}

The genus Bifidobacterium has been extensively studied because of its beneficial effects on health, especially the protection of the intestinal tract from microbial infection (Hamilton-Miller, 2003; Asahara et al., 2004). Several mechanisms have been proposed to explain the efficacy of bifidobacteria in preventing infection. Current study showed that the initial count of $E$. coli increased at the first day of storage in all samples of yoghurt (T1, T2 and T3) from $6.65 \log _{10}$ cfu/g to be $6.74,6.88$ and $6.85 \log _{10}$ $\mathrm{cfu} / \mathrm{g}$, respectively. The count of $E$. coli decreased gradually in $\mathrm{T} 2$ and $\mathrm{T} 3$ samples on the $3^{\text {rd }}$ day of storage with the mean values of 4.31 and $3.72 \log _{10}$ $\mathrm{cfu} / \mathrm{g}$, respectively. Then the reduction in bacterial population of $\mathrm{T} 2$ samples continued till $10^{\text {th }}$ day of storage recording a mean count of $2.04 \log _{10} \mathrm{cfu} / \mathrm{g}$ and disappeared completely on the $15^{\text {th }}$ and $10^{\text {th }}$ day of storage in T2 and T3, respectively (Fig. 1).

While in control T1 sample, the count of E. coli was still high on the $3^{\text {rd }}$ day of storage with a mean value of $6.74 \log _{10} \mathrm{cfu} / \mathrm{g}$ and began to decrease to be 5.00, 4.22 and $2.25 \log _{10} \mathrm{cfu} / \mathrm{g}$ at $7^{\text {th }}, 10^{\text {th }}$ and $15^{\text {th }}$ day of storage, respectively (Fig. 1). The obtained data concluded that the number of $E$. coli decreased by the end of storage period of yoghurt. However, the best bactericidal effect was observed in $\mathrm{T} 2$ and $\mathrm{T} 3$ samples and the lower effect was belonging to $\mathrm{T} 1$ sample. Similar results were reported by Farghaly (2004); Amer et al. (2010); Abdel-Aziz (2011).

Acid tolerance of $E$. coli was recorded in many researches as Halawa and Abou Zeid (2000) who found that $E$. coli persisted for up to 25 days in manufactured yoghurt. Benjamin and Datta (1995) who concluded that no loss of viability of $E$. coli O157:H7 at $\mathrm{pH}$ of 3.0 and 2.5 for $5 \mathrm{~h}$. Moreover King et al. (2010) mentioned that E. coli O157:H7 may have a greater ability to survive in more complex acidic environment such as those in the host and during food processing. It seems that the survival of E. coli in both low temperature and $\mathrm{pH}$ confirmed the implication of acidic food on some outbreaks due to E. coli infection (Sharp et al., 1995). As shown in this study, application of B. bifidum and B. longum in yoghurt manufacturing can restrict $E$. coli growth which claim to overcome the severe outbreaks from E. coli infection.

Data for the behavior of inoculated Staph aureus in cold storage yoghurt have been shown in Fig. (2). The population of Staph aureus showed decreased count in all yoghurt samples from $6.75 \log _{10} \mathrm{cfu} / \mathrm{g}$ to be 6.62, 6.51 and $6.38 \log _{10} \mathrm{cfu} / \mathrm{g}$ in T1, T2 and T3 on the first day of storage, respectively. Then its counts became 4.00, 3.85 and $3.55 \log _{10} \mathrm{cfu} / \mathrm{g}$, respectively on the $3^{\text {rd }}$ day of storage. Disappearance of Staph aureus population was observed on the $7^{\text {th }}$ day of storage in T3 sample followed by T2 sample on the $10^{\text {th }}$ day of storage, while the microorganism remain viable on $15^{\text {th }}$ day of storage in T1 sample. Similar results were obtained by Ahmed et al. (2002); Lengkey and Adriani (2009); Abdel-Aziz (2011). In addition, El-Shibiny et al. (2005) reported that bifidus yoghurt made from $B$. bifidum had almost similar flavor to standard yoghurt and both were very acceptable with good sensory characteristics which prevailed for 10 days of storage.

\section{Viability of E. coli and Staph aureus in low salt soft cheese}

E. coli counts recorded in Table 1 showed slightly decrease during storage period for control cheese (T1). On the other hand, addition of B. bifidum to cheese milk (T3) decrease of $E$. coli counts was pronounced, whereas $E$. coli disappeared in cheeses made with addition of either B. bifidum (T3) or B. longum (T5) on the $7^{\text {th }}$ day of storage. However, it remained in T1 up to 15 days of storage (Table 1). The above results are in agreement with that of Denkova et al. (2013) who indicated that the addition of $B$. bifidum to skimmed milk could reduce $E$. coli population from 9.1 $\log _{10} \mathrm{cfu} / \mathrm{ml}$ at zero time to zero after $72 \mathrm{~h}$ from incubation.

Lactic acid bacteria have potential applications as biopreservatives in the food industry (O'Sullivan et al., 2002). It inhibits the growth of some food spoilage and food-borne pathogens, such as Listeria monocytogenes, Staphylococcus aureus, E. coli and Clostridium botulinum (Cintas et al., 1997).

Staph aureus has been incriminated in many outbreaks of food poisoning. Cases of enterotoxin, food poisoning caused by consumption of cheese heavily infected with Staph aureus were observed. So their presence in large numbers in cheese regard as public health hazard. The growth of Staph aureus was recorded along of storage period in control cheese samples (T2). Its population increased significantly from $6.21 \log _{10} \mathrm{cfu} / \mathrm{g}$ at zero time to 6.79 $\log _{10} \mathrm{cfu} / \mathrm{g}$ at the $5^{\text {th }}$ day then lowered to 6.33 $\log _{10} \mathrm{cfu} / \mathrm{g}$ on $15^{\text {th }}$ day of storage (Table 1). This increase may be due to effect of salt that stimulate the growth of this bacterium (El-Zayat et al., 2008). However, Ahmed (1990) reported that the count of Staph aureus was affected by starter cultures and salt concentration.

On the other hand, for cheese made with B. bifidum (T4) and B. longum (T6), the count of Staph aureus was reduced significantly from $6.21 \log _{10} \mathrm{cfu} / \mathrm{g}$ at zero time to $1.04 \log _{10} \mathrm{cfu} / \mathrm{g}$ and $3.30 \log _{10} \mathrm{cfu} / \mathrm{g}$ at $5^{\text {th }}$ and $3^{\text {rd }}$ days of storage, respectively. Then it was not detected on the $7^{\text {th }}$ and $5^{\text {th }}$ days of storage for T4 and $\mathrm{T} 6$, respectively (Table 1). 
The current results are in agreement with that of Osman (1995), who reported that Staph aureus growth was inhibited by use of lactic starter culture during manufacturing of white soft cheese. Denkova et al. (2013) reported that Staph aureus is sensitive to $B$. bifidum when added to sterile skimmed milk and could reduce the population from $8 \log _{10} \mathrm{cfu} / \mathrm{ml}$ at zero time to be undetectable at $3^{\text {rd }}$ day. El-Abd et al. (2003) studied the effect of some LAB on the properties of low salt Domiati cheese and found that spore-forming and Staphylococci in the resultant cheese were lower than that of control cheese as well as the treated cheese showed a clear improved aroma, taste and marked early full ripening. In the same context, El-Shibiny et al. (2005) reported that soft cheese made with addition of B. bifidum was of good, acceptable flavor, smooth body, easily cut and handled with extended shelf-life to 20 days.

In general, probiotic soft cheese with $3 \%$ salt was superior to the control cheese and this superiority has been shown from the ability of both bifidobacterial species to inhibit the growth of both E. coli and Staph aureus. In the same context, Sobeih et al. (2011) reported that low salt soft cheese $(3 \% \mathrm{NaCl})$ with added Lactobacillus acidophilus culture at concentration of $3 \%$ had better organoleptic score, micrbiological quality and prolonged shelf-life (24 days) at refrigerated storage.

From the results achieved above, it was noticed that bifidobacteria had an inhibitory activity against E. coli and Staph aureus more than that of yoghurt culture bacteria and control soft cheese. This is may be due to the antimicrobial agents produced by bifidobacteria such as organic acids; mainly acetic and lactic acids (Bruno and Shah, 2002) and bacteriocins (Murad et al., 2000; Shah, 2001). To date, some bacteriocins such as bifidin 1 (Cheikhyoussef et al., 2010), bifidocin B (Yildirim and Jhonson, 1998; Yildirim et al., 1999) and bacteriocin-like inhibitory substances (BLIS) (Collado et al., 2005; Cheikhyoussef et al., 2009) have been reported to be produced by bifidobacteria, and have an inhibitory activities against wide range of Gram-positive and Gram-negative bacteria.

\section{REFERENCES}

Abdalla, M.; Davidson, P. and Christen, L. (1993): Survival of selected pathogenic bacteria in white pickled cheese made with lactic acid bacteria or antimicrobials. J. Food Prot., 56, 11: 972-976.

Abdel-Aziz, M.M. (2011): The role of bifidobacteria in improvement of physical, chemical and microbiological quality of fermented dairy products. Ph.D Thesis, Fac. Vet. Med., Benha Univ.
Ahmed, A.H. (1990): Prevalence and survival of enteropathogenic E. coli in yoghurt. Assiut Vet. Med. J., 22, 44: 95-100.

Ahmed, A.; Aideid, H.A.; Sherif, M.M. and Wehba, H.H. (2002): Effect of bifidobacteria on some pathogenic bacteria in yoghurt and on serum cholesterol level in rats. J. Egypt. Vet. Med. Assoc., 62, 66: 43-56.

Amer, A.; Aiad, A. and Abd-Allah, M. (2010): Effect of yoghurt processing and ice-cream manufacture on viability of some food borne bacteria. Assiut Vet. Med. J., 56, 127: 108-119.

APHA (American Public Health Association) (1992): Compendium of Methods for the Microbiological Examination of Foods. $3^{\text {rd }}$ ed., Public Health Association, Washington DC, USA.

Asahara, T.; Shimizu, K. and Nomoto, K. (2004): Probiotic bifidobacteria protect mice from lethal infection with Shiga toxin producing Escherichia coli O157:H7. Infect. Immun., 72, 4: 2240-2247.

Benjamin, M.M. and Datta, A.R. (1995): Acid tolerance of enterohemorrhagic Escherichia coli. J. Appl. Environ. Microbiol., 61: 1669-1672.

Bruno, F.A. and Shah, N.P. (2002): Inhibition of pathogenic and putrefactive microorganisms by bifidobacterium spp. Milchwiss., 57: 617-621.

Cheikhyoussef, A.; Pogori, N.; Chen, H.Q.; Tian, F.W.; Chen, W. and Tang, J. (2009): Antimicrobial activity and partial characterization of bacteriocin-like inhibitory substances (BLIS) produced by Bifidobacterium infantis BCRC 14602. Food Control, 20, 6: 553-559.

Cheikhyoussef, A.; Cheikhyoussef, N.; Chen, H.Q. ; Zhao, J.; Tang, J.; Zhang, H. and Chen, W. (2010): Bifidin 1- A new bacteriocin produced by Bifidobacterium infantis BCRC 14602: Purification and partial amino acid sequence. Food Control, 21, 6: 746-753.

Cintas, L.M.; Casaus, P. and Havarstein, L.S. (1997): Biochemical and genetic characterization of enterocin $\mathrm{P}$, a novel sec-dependent bacteriocin from Enterococcus faecium P13 with a broad antimicrobial spectrum. Appl. Environ. Microbiol., 63, 11: 4321-4330.

Clarke, G.M. and Kempson, R.E. (1997): Introduction to the design and analysis of experiments. Arnold, a Member of the Holder Headline Group. $1^{\text {st }}$ ed., London, UK.

Collado, M.C.; Hemandez, M. and Sanz, Y. (2005): Production of bacteriocin-like inhibitory compounds by human fecal bifidobacterium strains. Food Prot., 68, 5: 1034-1040.

Denkova, R.; Denkova, Z.; Yanakieva, V. and Blazheva, D. (2013): Antimicrobial activity of 
probiotic lactobacilli, bifidobacteria and propionic acid bacteria, isolated from different sources. Microbial Pathogens and Strategies for Combating them: Science, Technology and Education (Méndez-Vilas, A. Ed.)

Devlieghere, F.; Vermeiren, L. and Debevere, J. (2004): New preservation technologies: possibilities and limitations. Int. Dairy J., 14, 4: 273-286.

Duggan, C.; Gannon, J. and Allan Walker, W. (2002): Protective nutrients and functional foods for the gaterointestinal tract. Am. J. Clin. Nutr., 75, 5: 789.

El-Abd, M.; Abd El-Fattah, A.; Osman, S. and Abd El-Kader, R. (2003): Effect of some lactic acid bacteria on the properties of low salt domiati cheese. Egypt. J. Dairy Sci., 31: 125-138.

El-Sheikh, M.M.; Farrage, A.F.; Shahein, N.M. and El- Shibiny, S. (2001): Low fat Domiati cheese with particulate whey protein concentrate (PWPC). Egypt. J. Dairy Sci., 29: 331-342.

El-Shibiny, S.; Metwally, M.M.; Abd El-Gani, S.; Abd El-Fattah, A.M. and Okda, A.Y.M. (2005): Manufacture of some probiotic dairy products from ultrafiltered milk retentate. Egypt. J. Dairy Sci., 33: 215-227.

El-Zayat, A. (1988): The mode of action and cell destruction of disinfectants. Ph.D Thesis, Fac. Agric. Sci., Catholic Univ. Louvain, Belgium.

El-Zayat, A.; El-Safty, M.; El-Bagoury, E. and ElBackary, A. (1990): The microbial quality of raw materials and end products in Misr Milk and Food company. Egypt. J. Food Sci., 16: 151 .

El-Zayat, A.; Ahmed, H.A.; El-Backary, A.S. and Osman, M.M. (2008): Using of lactobacillus isolates as biopreservative cultures in some dairy products. Egypt. J. Dairy Sci., 36: 13-30.

Farghaly, M.H. (2004): Studies on Escherichia coli O157:H7 in milk and some milk products. Ph.D Thesis, Fac.Vet. Med., Assiut Univ.

Guarner, F. and Schaafsma, G.J. (1998): Probiotics. Int. J. Food Microbiol., 39, 3: 237-238.

Halawa, M.A. and Abou Zeid, A.M. (2000): Behavior of enterohemorrhagic Escherichia coli and enterotoxigenic Staphylococcus aureus in yoghurt and acidified milk. Vet. Med. J., Giza, 48, 2: 319-326.

Hamilton Miller, J.M. (2003): The role of probiotics in the treatment and prevention of Helicobacter pylori infection. Int. J. Antimicrob. Agents, 22, 4: 360-366.

Hull, P.R. and Robert, A.V. (1984): Differential enumeration of Lactobacillus acidophilus in yoghurt. Aust. J. Food Technol., 3: 160-164.

Kheadr, E.E.; Abd-El-Rahman, A.M. and El-Nemr, T.M. (2002): Survival of antimicrobial capacity of bifidobacteria and yoghurt bacteria during refrigerated storage of yoghurt made from lactose-hydrolyzed milk. Alex. J. Agric. Res., 47, 2: 81-91.

King, T.; Lucchini, S.; Hinton, J.C.D. and Gobius, K. (2010): Transcriptomic analysis of Escherichia coli O157:H7 and K-12 cultures exposed to inorganic and organic acids in stationary phase reveals acidulant- and strainspecific acid tolerance responses. Appl. Environ. Microbiol., 76, 9: 6514-6528.

Klaenhammer, T.R. and Kullen, M.J. (1999): Selection and design of probiotics. Int. J. Food Microbiol., 50, 1-2: 45-57.

Lengkey, H.A.W and Adriani, L. (2009): Effects of milk fermented with Lactobacillus acidophilus and bifidobacterium spp. on lactic acid and acetic acid content and on Staphylococcus aureus and Pseudomonas aeruginosa. Biotechnol. Animal Husbandry, 25 (5-6): 719-724.

Mehanna, A.S. and Rashed, M.A. (1990): An attempt to improve the keeping quality of Tallaga cheese by using milk treated with carbon dioxide. Egypt. J. Dairy Sci., 18: 377-388.

Montes, R.G.; Bayless, T.M.; Saavedra, J.M. and Perman, J.A. (1995): Effects of milks inoculated with Lactobacillus acidophilus or a yoghurt starter culture in lactose-maldigesting children. J. Dairy Sci., 78, 8: 1657-1664.

Murad, H.A.; Fatma, A.F. and Zeinab, I.S. (2000): Bacteriocinogenic effect of Bifidobacterium bifidum and some strains of lactic acid bacteria on growth of Staphylococcus aureus. Minufiya J. Agric. Res., 25, 3: 631-647.

O'Sullivan, L.; Ross, R.P. and Hill, C. (2002): Potential of bacteriocin-producing lactic acid bacteria for improvements in food safety and quality. Biochimie J., 84, 5-6: 593-604.

Osman, E. (1995): Behavior of Staphylococcous aureus in Turkish feta cheese during manufacture and ripening. J. Food Prot., 58, 11: 1201-1205.

Parodi, P.W. (1999): The role of intestinal bacteria in the causation and prevention of cancer: modulation by diet and probiotics. Aust. J. Dairy Technol., 54, 2: 103-121.

Piaia, M.; Antoine, J.M.; Mateos-Guardia, J.A.; Leplingard, A. and Lenoir-Wijnkoop, I. (2003): Assessment of the benifits of live yoghurt: Methods and markers for in vivo studies of the physiological effects of yoghurt cultures. Microbiol. Ecol. Health Dis., 15, 2-3: 79-87.

Robinson, R. (1991): Therapeutic Properties of Fermented Milks. Elsevier Science Publishers Ltd, London.

Robinson, R.K. and Tamime, A.Y. (1994): Manufacture of Yogurt and other fermented milks. In: Modern Dairy Technology, Advances in Milk Products. Robinson, R.K. 
(Ed.). London, Elsevier Applied Science. pp.: $1-48$.

Shah, N.P. (2001): Functional foods from probiotics and prebiotics. J. Food Technol., 55, 11: 46-53.

Sharp, J.C.M.; Reilly, W.J.; Coia, J.E.; Curnow, J. and Synge, B.A. (1995): Escherichia coli O157:H7 infection in epidemiological overview, 1984-1994. PHLS Microbiol. Digest., 12: 134-140.

Sobeih, A.M.; E.M. Ibrahim, E.M. and Elbarbary, H.A. (2011): Effect of Lactobacillus acidophilus on shelf-life of low salted cheese. Assuit Vet. Med. J., 57: 22-36.
Tamime, A.Y.; Marshall, V.E. and Robinson, R.K. (1995): Microbiological and technological aspects of milks fermented by bifidobacteria. J. Dairy Res., 62, 1: 151-187.

Yildirim, Z. and Jhonson, M.G. (1998): Characterization and antimicrobial spectrum of bifidocin B, a bacteriocin produced by Bifidobacterium bifidum NCFB. J. Food Prot., 61, 5: 47-51.

Yildirim, Z.; Winters, D.K. and Johnson, M.G. (1999): Purification of amino acid sequence and mode of action of bifidocin B produced by Bifidobacterium bifidum NCFB. J. Appl. Microbiol., 86, 1: 45-54.

\title{
استخذام بعض عزلات من البايفيدو بكتيريا كمزارع حفظ حيوية لبعض منتجات الألبان
}

\author{
هند أحمد البرييى
}

Email: hendbarbary2002@yahoo.com

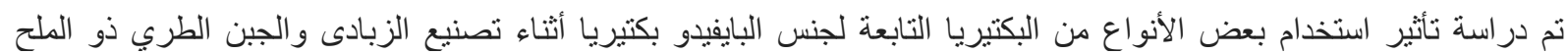

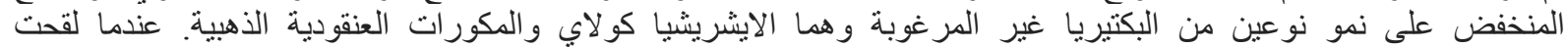

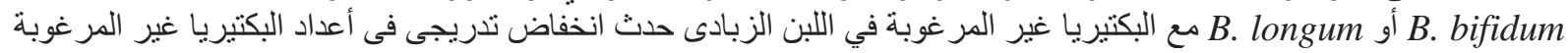

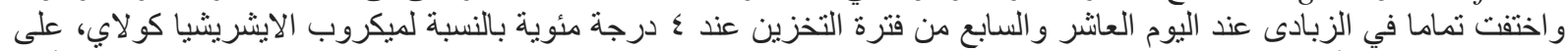

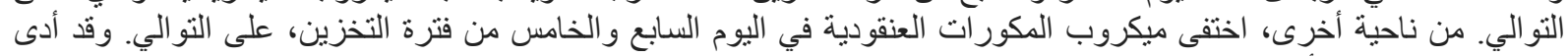

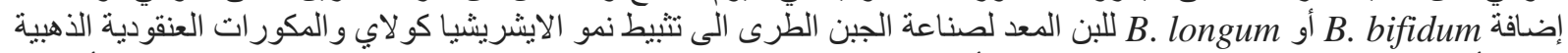

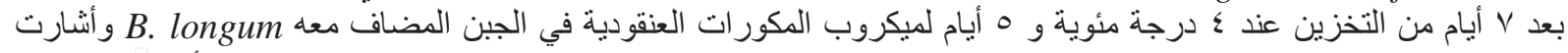

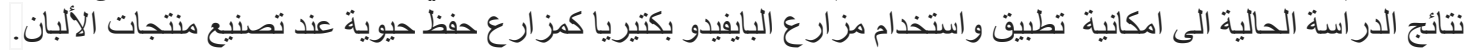

